ACTA THERIOLOGICA

Vol. 24, 3: $35-45,1979$

\title{
An Examination of Interspecific, Sexual and Individual Biases Affecting Rodent Captures in Longworth Traps
}

\author{
W. I. MONTGOMERY
}

Montgomery W.I., 1979: An examination of interspecific, sexual and individual biases affecting rodent captures in Longworth traps. Acta theriol., 24, 3: 35-45 [With 6 Tables]

Captures of Apodemus sylvaticus, A. flavicollis and Clethrionomys glareolus during six five-day trapping sessions were examined for biases. There was a significant tendency for captures to be in traps which had previously been successful and all species favoured traps which had captured conspecifics. These are probably related to spatial segregation in the rodent community. Male A. sylvaticus favoured traps in which males had been present while females entered traps previously occupied by males or females with equal probability. In $A$. flavicollis, males and females favoured traps previously occupied by a member of the opposite sex. In C. glareolus, captures of males and females were independent of the sex of previous occupants. Sexual biases are probably related to scent-marking and seem to deteriorate after one day. Individual $A$. flavicollis of both sexes tended to re-enter traps in which they had been captured more than $A$. sylvaticus. Male A. sylvaticus were significantly less prone to "repeat " captures than females.

[Dept. Zool., Univ. Manchester, Manchester M13 9PL, England]

\section{INTRODUCTION}

The capture-mark-recapture (C.M.R.) technique is one of the principal methods of estimating population size and other population parameters of rodents. One of the underlying assumptions of most C.M.R. techniques is that marked animals neither inhibit nor encourage the subsequent capture of unmarked animals or the subsequent recapture of the same or other marked individuals ( $\mathrm{S}$ o u thwood, 1966). However, there seems little reason to accept the validity of this assumption. For example, animals have been classed as trap "prone" or traps "shy" on the basis of frequency of recapture ( $\mathrm{T}$ a n t on, 1965; A ndr z e jew $\mathrm{ski}, \mathrm{Fe}$ jg i n \& Lir o, 1971). Heterogeneity in trap response of marked and unmarked animals has also been documented ( $\mathrm{Crow}$ croft \& J effers, 1961; Krebs, Keller \& T a marin, 1969). Others have related biases in trap response to the presence of faeces, urine and other

1 Present address: Dept. Zool., Queen's University Belfast, Belfast BT7 1NN, Northern Ireland. 
debris left by previous captives (Boonstra \& Krebs, 1976), and have indicated the influence of conspecific odours on the trappability of rodents ( $\mathrm{Mazdzer}$, C a pone \& Dri ckamer, 1976). This study reports the effects of captures of male and female Apodemus sylvaticus (L i n n a e u s, 1758), A. flavicollis (M e l c h i o r, 1834), and Clethrionomys glareolus ( $\mathrm{S} \mathrm{chr}$ e ber 1780) on subsequent captures in Longworth live traps (C hit ty \& K e m ps on, 1949).

\section{METHODS}

The study was carried out in the deciduous woodland of Woodchester Park, a steep-sided valley in Gloucestershire, England. Traps were set on a grid (marked out by C. J. Roberts, Department of Biology, University of Southampton) in Leaze Wood. The woodland of Leaze Wood is dominated by Taxus, Fagus, Ulmus (mostly diseased), Fraxinus, Prunus, Sambucus, Buxus, Rubus, Mercurialis, Urtica and Alium. The wood is adjacent to the rough pasture of the valley floor and verges on the gardens of the field station. The grid was marked out in a continuous belt of woodland and consisted of eight rows, $A$ to $H$ each $10 \mathrm{~m}$ apart, with twelve points, 1 to 12 , at $10 \mathrm{~m}$ intervals along each row. Two traps were set in each trap station for five consecutive mights during February, April, June, August, October and December, 1975. At each point of the grid one trap was designated "west « or "east «, "north « or "south " making it possible to record the history of captures in each of 192 traps during each trapping session. The nest box of each trap contained hay and $2-3$ grams of wheat grain. Traps were cleaned between trapping session and the hay replaced. Wheat grain was replenished after each capture.

A.sylvaticus, A. flavicollis and C. glareolus were the dominant species among captures on the Leaze Wood grid. Captures of Sorex araneus, S. minutus, Neomys fodiens and Mustela nivalis were infrequent and were therefore ignored in this analysis. Rodents were sexed and individually marked using a combination of ear punching and toe clipping (Fullagar \& Jewell, 1965). Juveniles were captured during the breeding seasons but these were omitted from the data and consideration is given only to interspecific biases and those between males and females.

\section{RESULTS}

Capture data were analysed with respect to captures at time $t$ and time $t+x$ where $t$ is any day to day 4 of the trapping period of five days, and $x$ is $1,2,3$ or 4 days. At $t$, each trap may catch nothing, a male or female. A. sylvaticus, a male or female A. flavicollis or a male or female $C$. glareolus. These seven possibilities also occur at $t+x$. Thus a $7 \times 7$ contingency table was constructed for each value of $x$ using the trap data from each of the six trapping sessions and for the data lumped for the whole of 1975. This method is illustrated in Table 1 which presents the number of captures at $t$ and $t+x$, where $x$ is $1,2,3$ or 4 , during all trapping sessions. (Individuals caught in the same trap at $t$ and 
Table 1

Captures at time $t$ and $t+x$ when $x$ is $1,2,3$ or 4 . Data for all trapping sessions are lumped.

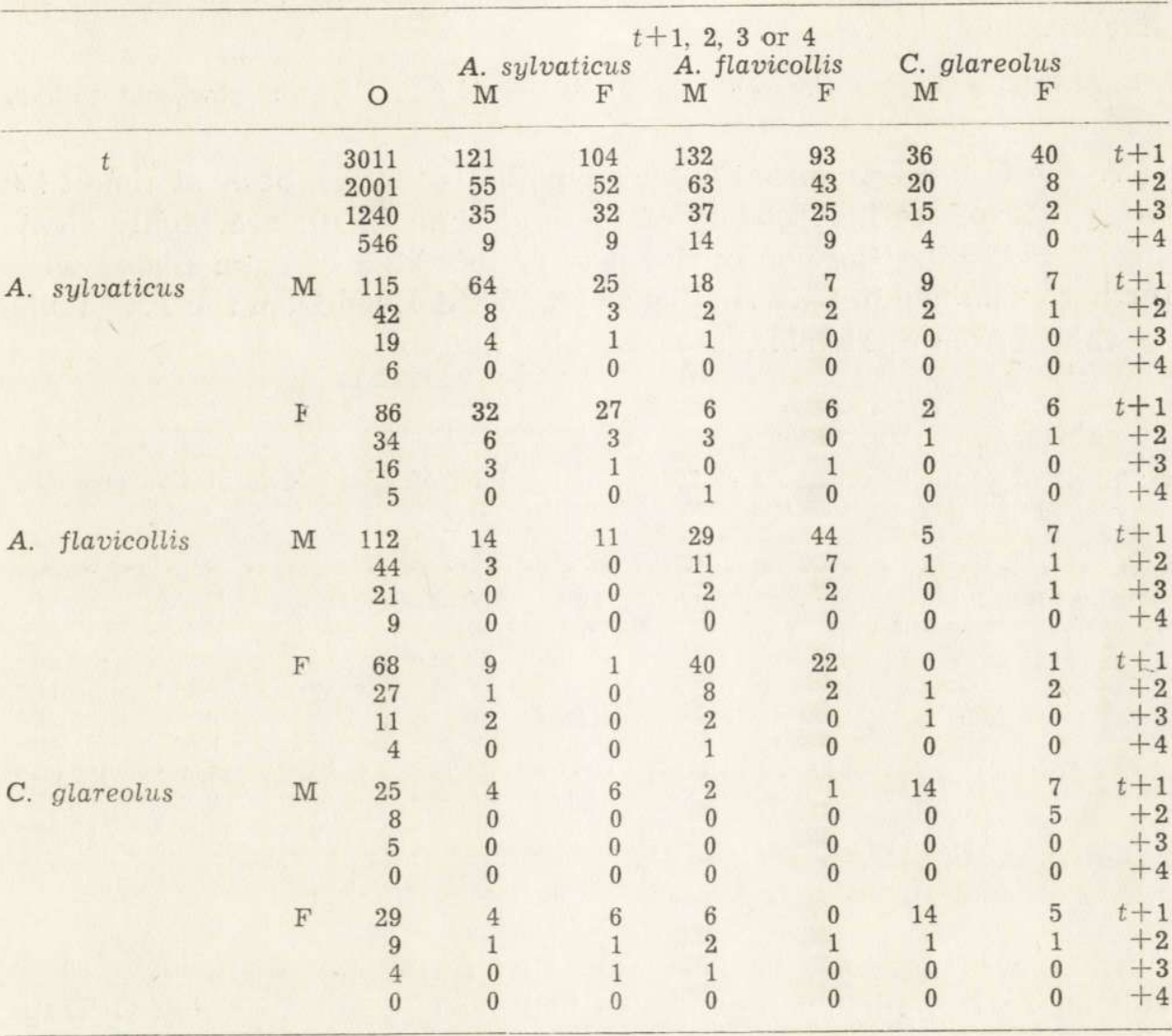

$t+x$, that is repeat « captives, will be considered separately. These have been omitted from the present analysis).

\subsection{Captures at $t$ and $t+1$}

Values of $\chi^{2}$ in $G$-tests of overall heterogeneity (Sokal \& Rohlf, $1969)$ in the $7 \times 7$ contingency table of captures at $t$ and $t+1$, for each trapping session and for lumped data, are presented in Table 2. (The

Table 2

Values of $\chi^{2}$ in $G$-tests of overall heterogeneity in $7 \times 7$ contingency tables of captures on day $t$ and $t+1$ for each trapping session and lumped. data. All values are significant at the $.01 \%$ level.

\begin{tabular}{lcccccc}
\hline Feb. & Apr. & Jun. & Aug. & Oct. & Dec. & Lumped data \\
99.9 & 115.9 & 230.0 & 137.7 & 107.6 & 217.9 & 803.8
\end{tabular}


$G$-test is a test of the independence of two classes of observations and is more convenient than the chi-square test when there are more than two columns or rows. The computation of $\chi^{2}$ in the $G$-test follows the simple rule

$$
\begin{array}{r}
G=2[(\Sigma f \ln f \text { for the cell frequencies })-(\Sigma f \ln f \text { for the row and column } \\
\text { totals })+n \ln n]
\end{array}
$$

Here the $G$-test examines the null hypothesis that captures at time $t+x$ in each trap, are independent of those at time $t$ ). All are highly significant, indicating the non-randomness of this kind of data. Biases were further examined in $2 \times 2$ contingency tables derived from the $7 \times 7$ table. $\tau_{1}{ }^{2}$ values from these tables are presented in Table 3.

Table 3

Analysis of captures on day $t$ and day $t+1$ : values of $\chi_{1}^{2}$ in tests of heterogeneity

\begin{tabular}{|c|c|c|c|c|c|c|c|}
\hline $\begin{array}{l}2 \times 2 \\
\text { Contingency table }\end{array}$ & Feb. & Apr. & Jun. & Aug. & Oct. & Dec. & $\begin{array}{l}\text { Lumped } \\
\text { data }\end{array}$ \\
\hline Capture/Absence & $63.62 *$ & $71.30 *$ & $148.00 *$ & $54.14 *$ & $65.22 *$ & $116.30 *$ & $549.00^{*}$ \\
\hline A.s. $\quad \mathrm{M} / \mathrm{F}$ & 1.09 & 0 & .67 & 1.40 & .33 & $9.40^{*}$ & $4.11 *$ \\
\hline $\mathrm{M} / \mathrm{F}$ & 1.40 & 0 & $16.43 *$ & 0 & 2.47 & 0 & $7.28 *$ \\
\hline $\mathrm{M} / \mathrm{F}$ & & & .01 & .10 & & .06 & .68 \\
\hline A.s./A.f & 1.71 & $19.39 *$ & $27.49 *$ & $14.35 *$ & $11.89 *$ & $35.75 *$ & $122.80 *$ \\
\hline A.s./C.g. & 2.17 & & $7.27 *$ & $17.85 *$ & $3.98 *$ & 2.25 & $95.67^{*}$ \\
\hline A.f./C.g. & & & $23.60 *$ & $10.21 *$ & $7.69 *$ & $14.50 *$ & 59.26 * \\
\hline
\end{tabular}
in specified $2 \times 2$ contingency tables.

* significant at the $5 \%$ levei or better.

There was a strong tendency during all trapping sessions to catch animals on day $t+1$ in traps which had been occupied on day $t$. Traps which did not catch anything on day $t$ rarely succeeded on the following day of the trapping session. This may indicate that such traps are poorly placed or set in areas of the grid not frequented by any of the rodent species. Alternatively rodents may be wary of entering clean traps or are more attracted to dirty ones. This phenomenon has been described for Microtus populations by Boonstra \& Krebs (1976).

A male $A$. sylvaticus was often followed by another male while females followed males and other females with equal probability. This tendency was significant only in December and when data for the entire trapping program was lumped. This is difficult to explain but may reflect the partial segregation of male and female $A$. sylvaticus during the non-breeding period described by $\mathrm{R}$ andolph (1977). However, there was no evidence to support this contention in the spatial distribution of captures of male and female A. sylvaticus in Leaze Wood (Mon t g o m er y, 1977). 
These biases differ markedly from those among $A$. flavicollis, where a male was often followed by a female while females were often followed by males. Biases in A. flavicollis captures were only significant in June and for the lumped data. They may reflect changes in social behaviour such that males and females associate more with one another during the breeding season than in the nonbreeding period.

Captures of C. glareolus did not contain any biases even when the data was lumped and, in this species, captures at $t$ and $t+1$ were random with respect to sex.

In all trapping sessions, capture of one Apodemus species at $t$ tended to be followed by a conspecific at $t+1$; thus $A$. sylvaticus and A. flavicollis were rarely caught in the same trap on consecutive days of the trapping period. This tendency is significant in all months bar February (Table 3). Similarly A. sylvaticus and C. glareolus were significantly biased against being caught in the same trap on consecutive days as were A. flavicollis and C. glareolus. This suggests that each species may recognise traps in which conspecifics have been present and are encouraged to enter. Alternatively, if A. sylvaticus, A. flavicollis and C. glareolus are spatially segregated within the woodland, each species may be caught in traps placed in suitable habitat for that species.

3.2 Captures at $t$ and $t+2,3$ or 4

In an effort to distinguish between these alternative hypotheses, captures on day $t$ and $t+x$ where $x$ is more than 1 , and where no captures occur between $t$ and $t+x$, were examined. If traps are marked in some way by the presence of one species, one might expect this to deteriorate in time and thus species biases in captures should disappear

Table 4

Analysis of captures on day $t$ and subsequently on day $t+x$ when $x=1,2,3$ or 4 : values of $\chi^{2}$ in $G$-tests of overall heterogeneity in $7 \times 7$ contingency tables. Data for all trapping sessions have been lumped.

\begin{tabular}{cccc}
\hline$t$ to $t+1$ & $t$ to $t+2$ & $t$ to $t+3$ & $t$ to $t+4$ \\
\hline $803.83^{*}$ & $151.98^{*}$ & 62.79 & 11.12 \\
\hline
\end{tabular}

as $x$ becomes larger. However, if the biases are derived from habitat differences, they should persist regardless of the interval between $t$ and $t+x$. Unfortunately the number of traps with captures at $t$ and $t+x$ decreases as $x$ increases so data for all trapping sessions has been lumped for this analysis.

The overall heterogeneity, tested using the G-test, decreases but is significant to $x=3$ (Table 4). The nonrandom capture of sexes of both 
Apodemus species disappears if the interval between $t$ and $t+x$ is greater than one day. However, the tendency for conspecifics to be captured in the same trap at $t$ and $t+x$ persists to $x=3$ with respect to A. sylvaticus and A. flavicollis, and $x=2$ with respect to either Apodemus species and C. glareolus (Table 5). This seems to support the hypothesis that interspecific biases of captures in Longworth traps are due to spatial segregation. Biases between sexes seem to be based on captives marking traps possibly by the scent of urine or faeces, so increasing the likelihood of the subsequent capture of one sex relative to the other.

\section{Table 5}

Analysis of captures on day $t$ and day $t+x$ when $x=1,2,3$ or 4 : values of $\chi_{1}{ }^{2}$ in test of heterogeneity in specified $2 \times 2$ contingency tables. Data for all trapping sessions are lumped. Omissions indicate paucity of data.

\begin{tabular}{lcccc}
\hline $2 \times 2$ contingency table & $t$ to $t+1$ & $t$ to $t+2$ & $t$ to $t+3$ & $t$ to $t+4$ \\
\hline capture/absence & $549.00^{*}$ & $95.00^{*}$ & $13.50 *$ & .13 \\
A. sylvaticus M/F & $4.11^{*}$ & .38 & .39 & \\
A. flavicollis M/F & $7.28^{*}$ & .36 & .09 & \\
C. glareolus M/F & .68 & .26 & \\
A. sylvaticus/A. flavicollis & $122.80^{*}$ & $20.53^{*}$ & $4.02^{*}$ & \\
A. sylvaticus/C. glareolus & $95.67^{*}$ & $7.30^{*}$ & 0 & \\
A. flavicollis/C. glareolus & $59.26^{*}$ & $8.91^{*}$ & .50 & \\
\hline
\end{tabular}

* significant at the $5 \%$ level or better.

\subsection{Repeat Captures}

The incidence of repeat captures, that is capture of the same individual in the same trap on $t$ and $t+x$, was examined with respect to. the number of conspecifics and of the samesex occurring at $t$ and $t+x$. There was a tendency for individuals of both sexes in all species to re-enter traps in which they were previously captured (Table 6). In A. sylvaticus, males were less likely than females to be caught in the same trap on consecutive days $\left(\chi_{1}^{2}=6.29 ; P<.05\right)$. This could be due to the less sedentary life of the male indicated by many authors, for example Brown (1969) and Randolph (1977). This effect was also seen among $C$. glareolus captures though here it was not significant $\left(x_{1}^{2}=1.42 ; P>.05\right)$. However, among $A$. flavicollis captures, repeat captures were equally frequent in males and females and were significantly more frequent in this species as a whole than in $A$. sylvaticus $\left(\chi_{1}^{2}=5.35 ; P<.05\right)$. This perhaps reflects differences in social behaviour between $A$. flavicollis and A. sylvaticus or $C$. glareolus.

As $x$ increases, data for captures on $t$ and $t+x$ decreases and 
analysis is only possible when data for $x$ greater than 1 is lumped (Table 6). For values of $x+1$, repeat captures among male $A$. sylvaticus were less frequent than among females though this disparity was not significant $\left(\chi_{1}^{2}=2.25 ; P>.05\right)$. The disparity between $A$. sylvaticus and $A$. flavicollis with respect to repeat captures ceases when the interval between $t$ and $t+x$ is greater than 1 day $\left(\chi_{1}^{2}=1.00 ; P>.05\right)$.

Table 6

Number of repeat captures ("same" individual) and captures of conspecifics of the same sex ("diff. $"=$ different) in traps on $t$ and $t+x$ when $x=1,2,3$ or 4.

\begin{tabular}{|c|c|c|c|c|c|c|c|c|c|c|}
\hline & $\begin{array}{r}t \text { to } \\
\text { same }\end{array}$ & $\begin{array}{l}t+1 \\
\text { diff. }\end{array}$ & $\begin{array}{l}t \text { to } \\
\text { same }\end{array}$ & $\begin{array}{c}t+2 \\
\text { diff. }\end{array}$ & $\begin{array}{r}t \text { to } \\
\text { same }\end{array}$ & $\begin{array}{c}t+3 \\
\text { diff. }\end{array}$ & $\begin{array}{r}t \text { to } \\
\text { same }\end{array}$ & $\begin{array}{l}t+4 \\
\text { diff. }\end{array}$ & $\begin{array}{r}\text { sum } \\
t+x \mathrm{u} \\
\text { sam }\end{array}$ & $\begin{array}{l}\text { f } t \text { to } \\
\text { 1en } x>1 \\
\text { diff. }\end{array}$ \\
\hline \multicolumn{11}{|c|}{ A. sylvaticus } \\
\hline M & 42 & 64 & 8 & 8 & 3 & 4 & 0 & 0 & 11 & 12 \\
\hline $\mathrm{F}$ & 41 & 27 & 9 & 3 & 3 & 1 & 1 & 0 & 13 & 4 \\
\hline \multicolumn{11}{|c|}{ A. flavicollis } \\
\hline M & 48 & 29 & 5 & 11 & 3 & 2 & 1 & 0 & 9 & 13 \\
\hline $\mathrm{F}$ & 34 & 22 & 4 & 2 & 0 & 0 & 0 & 1 & 4 & 3 \\
\hline \multicolumn{11}{|c|}{ C. glareolus } \\
\hline M & 10 & 14 & 2 & 0 & 0 & 0 & 0 & 0 & 2 & 0 \\
\hline $\mathrm{F}$ & 10 & 5 & 4 & 1 & 0 & 0 & 0 & 0 & 4 & 1 \\
\hline
\end{tabular}

In $A$. flavicollis, there were fewer repeat captures when $x>1$ than when $\mathrm{x}=1$ though this difference was not significant $\left(\chi_{1}^{2}=2.13 ; P>.05\right)$; in A. sylvaticus there were more repeat captures when $x>1$ than when $x=1$ but, again, this difference was not significant $\left(\chi^{2}{ }_{1}=1.48\right.$; $P>.05)$. Nor were $A$. sylvaticus and $A$. flavicollis significantly different in this respect $\left(\chi_{1}^{2}=2.02 ; P>.05\right)$. However, there seems to be some indication that the likelihood of a repeat capture changes when $x$ is greater than 1 and this may be due to the deterioration of scent marks left in traps.

\section{DISCUSSION}

Calhoun (1964) has suggested that olfactory stimulation may alter the probability of rodent capture. In the present study, the presence of a given individual often depressed or increased the likelihood of capture of conspecifics and individuals of other species in the same trap on a subsequent day. However, olfaction is not the only factor influencing captures of $A$. sylvaticus, $A$. flavicollis and $C$. glareolus. Each rodent species was found to have habitat preferences within the woodland of the study site (Montgomery, 1977); all three species tended to avoid areas of dense high canopy below which there was little cover and the ground was bare but for a little leaf litter. This was reflected, perhaps, by the tendency for traps which had 
failed to capture animals one day, to be unsuccessful on subsequent days (Tables 3 and 5). A. sylvaticus, A. flavicollis and C. glareolus were partially segregated on the Leaze Wood grid and there were significant biases in all species for animals to be captured in traps which had previously caught a conspecific. These persisted even in examination of captures separated by up to three days (Table 5). This suggests that interspecific biases are derived from habitat preferences, as indicated by T u r č e k (1960) who described biases in the sequence of C. glareolus and $A$. flavicollis in snap traps, rather than induced by scent marking which could decrease the likelihood of capturing individuals of other species. However, there is evidence of direct aggression between $A$. flavicollis and C.glareolus; Andrzejewski \& Olszewski (1963), for example, found $A$. flavicollis to be overtly agonistic towards $C$. glareolus which was invariably subordinate in interspecific encounters. In multiple-capture traps, the presence of A. flavicollis inhibits the trappability of $C$. glareolus though the presence of the latter does not effect the capture of the former ( $\mathrm{Kal}$ inow ska, 1971). This suggests that interspecific biases in captures in Longworth traps depends not only one the distribution of each species within the woodland, but also on subordinate species avoiding dominant species or areas in which aggression has been experienced.

Mazdzer et. al. (1976) have found that male and female Perymyscus leucopus favour traps scented with the urine of the opposite sex. This effect was also seen in A. flavicollis and was most clearly discernable in June. Biases of this nature probably reflect mate finding behaviour. However, in A. sylvaticus, males favour traps in which other males have been present while females show no preference for traps occupied by either males or females (Table 3). Male-seeking behaviour may be an important feature of social behaviour in A. sylvaticus. Brown $(1966,1969)$ and Bovet $(1972)$ have suggested the existence of male hierarchies in A. sylvaticus and these could be maintained by males actively seeking each other. In this case, the social behaviour of A. sylvaticus seems fundamentally different from that of $A$. flavicollis.

These sexual biases in A. sylvaticus and A. flavicollis are probably based on the olfactory stimulis provided by faeces, urine and other debris left in traps by captives. These cues were of limited durability, the biases being absent if the time between the initial and the subsequent capture was greater than one day (Table 5). It seems unlikely that odours of this nature play an important role in marking home ranges or maintaining territories but solely identify the owner as a male or female. However, individual recognition by odour has been reported in, for example, Meriones unguiculatus ( $\mathrm{H} \mathrm{alp} \mathrm{in,} \mathrm{1974)} \mathrm{and}$ 
Mus musculus (Bowers \& A lexander, 1967) so olfaction in Apodemus may be developed beyond differentiation betwen males and females.

A. sylvaticus and $A$. flavicollis also differed from one another with respect to the incidence of repeat captures; individual $A$. sylvaticus vere less prone than individual $A$. flavicollis to be caught in the same trap on consecutive nights (Table 6). In A. sylvaticus, repeat captures of males were relatively less common than those of females. The incidence of repeat captures was equal among male and female $A$. javicollis. These interspecific and intraspecific differences ceased to be significant when the interval between initial and subsequent captures was more than one day. This suggests that rodents may return to a trap in which they were captured, finding it by memory, and re-enter because the trap is scented by their own scent. This also implies that individual Apodemus are capable of recognising their own scent.

Rajska-Jurgiel (1976), using a double live trap method, has demonstrated that the presence of a sexually active male or female C. glareolus is disproportionately attractive to the oposite sex. This effect was not apparent in the present study and male and female C. glareolus captures succeeded those of conspecifics of both sexes with equal probability (Table 3 ). The incidence of repeat captures among males was greater, though not significantly so, than among female $C$. glareolus. Soiled traps seem to influence the trappability of $C$. glareolus less than they influence the trappability of Apodemus species. This suggests that olfaction is less important in C. glareolus than in Apodemus species.

Biases in the trappability of conspecifics may have important consequences for C.M.R. methods of estimating populations. In this study, the presence of an animal in a trap affected the chances of catching others of either sex on the following day. For example, among $A$. sylvaticus captures, males followed other males. This could increase the proportion of males captured relative to the proportion of females captured and lead to over estimation of the population. This may be avoided by estimating the male and female portions of the population separately or by ensuring that the number of traps available to each rodent is high. If a large number of traps are encountered by each animal some will be attractive, some inhibitive and others unaffected; the overall probability of capture of all classes of animals would then remain equal.

Acknowledgements: It is a pleasure to thank Mr. A.R. Kelly who granted access at Woodchester Park and Dr. D.W. Yalden who supervised this study. The work was carried out while the author was in receipt of a post-graduate award from the Department of Education for Northern Ireland. 


\section{REFERENCES}

1. Andrzejewski R., Fejgin H. \& Liro A., 1971: Trappability of trapprone and trap-shy bank voles. Acta theriol. 16: 401-405.

2. Andrzejewski R., \& Olszewski J., 1963: Social behaviour and interspecific relations in Apodemus flavicollis (Melchior, 1834) and Clethrionomys glareolus (S chreber, 1780). Acta theriol. 7: 155-168

3. Boonstra R. \& Krebs C.J., 1976: The effect of odour on trap response in Microtus townsendii. J. Zool., Lond. 180: 467-476.

4. Bovet J., 1972: On the social behaviour in a stable group of long-tailed field mice (Apodemus sylvaticus): 2. Its relations with distribution of daily activity. Behaviour, 41: 55-67.

5. Bowers J.M. \& Alexander B.K., 1967: Mice: individual recognition by olfactory cues. Science, N.Y. 158: 1208-1210.

6. Brown L.E., 1966: Home range and movement of small mammals. Symp. zool. Soc. Lond. 18: 111-142.

7. Brown L.E., 1969: Field experiments on the movements of Apodemus sylvaticus using trapping and tracking techniques. Oecologia, 2: 198-222.

3a. Calhoun J.B., 1964: The social use of space. [In: "Physiological mammalogy", eds. W. Mayer, R. van Gelder]. Academic Press, vol. 1: 1-187. New York.

8b. Chitty D. \& Kempson D.A., 1949: Pre-baiting small mammals and a new design of live trap. Ecology, 30: 536-542.

9. Crowcroft P. \& Jeffers J.N.R., 1961: Variability in the behaviour of wild house mice (Mus musculus L.) towards live traps. Proc. zool. Soc. Lond., 137: $573-582$.

10. Fullagar P.J. \& J ewe 11 P.A., 1965: Marking small rodents and the difficulties in using leg rings. J. Zool., Lond. 147: 224-228.

11. Halpin Z.T., 1974: Individual differences in the biological odours of the Mongolian gerbil (Meriones unguiculatus). Behav. Biol., 253-259.

12. Kalinowska A., 1971: Trapping of Apodemus flavicollis and Clethrionomys glareolus into a double trap. Acta theriol. 16: 73-78.

13. Krebs C.J., Keller B.L. \& Tamarin R.H., 1969: Microtus population biology: demographic changes in fluctuation populations of $M$. ochrogaster and M. pennsylvanicus in southern Indiana. Ecology, 50: 577-607.

14. Mazdzer E., Capone M.R. \& Drïckamer L.C., 1976: Conspecific odors and trappability of deer mice (Peromyscus leucopus noveboracensus). J. Mammal., 57: 607-609.

15. Montgomery W.I., 1977: Studies on the ecology of two sympatric species of Apodemus (Rodentia: Muridae). Unpublished Ph. D. thesis, University of Manchester.

16. Rajska-Jurgiel E., 1976: Interactions between individuals of a population of the Bank vole, Clethrionomys glareolus (Schreber, 1780). Ekol. pol. 24: $3-35$.

17. $\mathrm{R}$ andolph S.E., 1977: Changing spatial relationships of Apodemus sylvaticus with the onset of breeding. J. Anim. Ecol, 46: 653-676.

18. Sokal R.R. \& Rohlf F.J., 1969: Biometry: the principles and practice of statistics in biological research. Freeman: 1-776. San Frascisco.

19. Southwood, T.R.E., 1966: Ecological methods. Methuen: 1-391. London.

20. Tanton M.T., 1965: Problems of live trapping and population estimation for the woodmouse, Apodemus sylvaticus. J. Anim. Ecol., 34: 1-22. 
21. Turček F.J., 1960: Sidelné vstahy niektorych lesńych hlvdavcev zistene na podklade mapovania. Biologia, Bratisl., 15: 729-736.

Accepted, August 10, 1978.

W.I. MONTGOMERY

ODDZIAEYWANIA MIĘDZYGATUNKOWE, PECIOWE I INDYWIDUALNE NA ODEOWY GRYZONI W PUŁAPKI LONGWORTH

Streszczenie

W analizie uwzględniono trzy gatunki: Apodemus sylvaticus, A. flavicollis i Clethrionomys glareolus odlawiane podczas sześciu 5-dniowych okresów odłownych. Materiał podzielony na gatunki i płeć analizowano $w$ tabeli wielodzielczej $(7 \times 7)$ (Tabela 1). U wszystkich trzech gatunków stwierdzono statystycznie istotną tendencję do lowienia się $w$ te pułapki, które wcześniej już były odwiedzane przez zwierzęta (Tabele 2 i 3), co wynika prawdopodobnie z przestrzennego rozmieszczenia zespołu gryzoni. Samce $A$. sylvaticus preferują pułapki w które poprzednio lowiły się także samce (istotne zależności wystąpiły tylko w grudniu i dla danych sumarycznych), natomiast odłowy samic pod tym względem są przypadkowe. A. flavicollis ma tendencje do odwiedzania pułapek, w których poprzednio były osobniki odmiennej plci, natomiast u C. glareolus lowność nie jest zależna od płci osobnika poprzednio złowionego w daną pułapkę (Tabela 1). Sugerowano, że oddziaływania dotyczące płci łowionych osobników związane są ze znakowaniem zapachowych pułapek, które po pewnym czasie przestaje działać (Tabele 4 i 5). Osobniki $A$. flavicollis (obu płci) w większym stopniu miż osobniki A. sylvaticus mają tendencję do ponownego łowienia się $w$ te same pułapki, natomiast samce $A$. sylvaticus w istotnie mniejszym stopniu niż samice lowią się powtórnie, podobnie jest też u C. glareolus (Tabela 6). Zróżnicowanie to prawdopodobnie odzwierciedla różnice $\mathrm{w}$ behawiorze socjalnym tych trzech gatunków gryzoni. 